\title{
The Leiognathus aureus complex (Perciformes: Leiognathidae) with the description of a new species
}

\author{
Seishi Kimura ${ }^{1 凶}$, Paul V. Dunlap², Teguh Peristiwady ${ }^{3}$, and Celia R. Lavilla-Pitogo ${ }^{4}$ \\ ${ }^{1}$ Fisheries Research Laboratory, Mie University, P. O. Box 11, Wagu, Shima, Mie 517-0703, Japan \\ (e-mail: kimura-s@bio.mie-u.ac.jp) \\ ${ }^{2}$ Department of Ecology and Evolutionary Biology, University of Michigan, 830 North University Avenue, Ann Arbor, \\ MI 48109-1048, USA (e-mail:pvdunlap@umich.edu) \\ ${ }^{3}$ Research Center for Oceanology, Indonesian Institute of Sciences, Jl. Pasir Putih I, Ancol Timur, Jakarta 12870, Indonesia \\ (e-mail: ikan_teguh@yahoo.com) \\ ${ }^{4}$ Southeast Asian Fisheries Development Center, Tigbauan 5021, Iloilo, Philippines (e-mail: celiap@aqd.seafdec.org.ph)
}

Received: December 13, 2002 / Revised: March 13, 2003 / Accepted: March 14, 2003

\begin{tabular}{c}
\hline Ichthyological \\
Research \\
@The Ichthyological Society of Japan 2003 \\
\hline
\end{tabular}

Ichthyol Res (2003) 50: 221-232

DOI 10.1007/s10228-003-0160-Z

\begin{abstract}
Taxonomic analysis of a group of morphologically similar ponyfishes (Perciformes: Leiognathidae) establishes a complex comprising three valid species: Leiognathus aureus Abe and Haneda, 1972, widely distributed in the western Pacific Ocean (Taiwan, Philippines, Thailand, Singapore, Indonesia, and northern Australia); L. hataii Abe and Haneda, 1972, currently known only from Ambon, Indonesia; and L. panayensis sp. nov. Kimura and Dunlap, currently known only from Panay Island, the Philippines. The L. aureus complex can be defined by the following combination of characters: mouth protruding forward, not downward; small but sharp conical teeth uniserially on jaws; a black line between lower margin of eye and lower jaw articulation; and lateral line incomplete, ending below posterior part of dorsal fin base or on anterior caudal peduncle. Leiognathus hataii differs from both L. aureus and L. panayensis in having a large dark blotch below the spinous dorsal fin base and fewer counts of scales (lateral line scales $50-58$ vs. 64-85 in the latter two species; scales above lateral line $7-10$ vs. $12-18$; scales below lateral line $22-26$ vs. 30-41). Leiognathus panayensis is distinguished from $L$. aureus in having a deeper body (41-51\% SL vs. 35-45\% SL in the latter), long posterior limb of maxilla (21-25\% HL vs. 15-23\% HL), wholly scaled belly (vs. naked along preanal median keel), and a dark blotch on nape (vs. absent).
\end{abstract}

Key words Leiognathus aureus complex $\cdot$ Leiognathus aureus $\cdot$ Leiognathus hataii $\cdot$ Leiognathus panayensis sp. nov. Neotype
$\mathrm{T}$ he Leiognathidae, an Indo-Pacific family of fishes, comprises three genera: Gazza Rüppell, 1835 (characterized by a forward-protruding mouth and large canine teeth on jaws), Leiognathus Lacepéde, 1802 (a forward- or downward-protruding mouth and small or minute teeth on jaws), and Secutor Gistel, 1848 (an upward-protruding mouth and minute teeth on jaws) (see James, 1975,1984; Jones, 1985; Mochizuki and Hayashi,1989; Kimura and Peristiwady,2000; Woodland et al., 2001). Of these genera, the validity of the species belonging to Gazza and Sector largely has been resolved recently (Mochizuki and Hayashi, 1989; Yamashita et al.,1998,2001; Kimura et al.,2000). However, species in the genus Leiognathus still present considerable taxonomic difficulty, despite various family-level revisions (James, 1975, 1984; Jones, 1985; Shen and Lin, 1985; Woodland et al., 2001), because of the morphological similarity of many species. In this study, we address this problem by characterizing three morphologically very similar members of the genus Leiognathus: L. aureus, L. hataii, and a new species.

Leiognathus aureus and L. hataii were described originally by Abe and Haneda (1972) from a limited number of specimens collected at Ambon fish market, Ambon, Indonesia. Since then, $L$. hataii has not been reported from any location except by Woodland et al. (2001), who listed the species among the leiognathid fishes occurring in the Western Central Pacific; however, this species was not included in the key to the species or the species accounts. Furthermore, L. aureus has been reported only from Jakarta, Indonesia (Mochizuki et al., 1985), northern Australia (Jones, 1985), and the Banda Sea and the Arafura Sea (Woodland et al., 2001). Both species are very similar in general appearance and share some characteristics that, on the basis of the original descriptions, distinguish them from congeners. However, the identification of characters diagnostic of each of these two species has been lacking due to incomplete original descriptions and loss of the type specimens of both species (K. Sakamoto, personal communication).

Our field surveys in Southeast Asia and examination of museum specimens revealed that L. aureus is distributed widely, occurring in Taiwan, the Philippines, Thailand, Singapore, Indonesia, and northern Australia, and that a new Leiognathus species closely resembling L. aureus and 


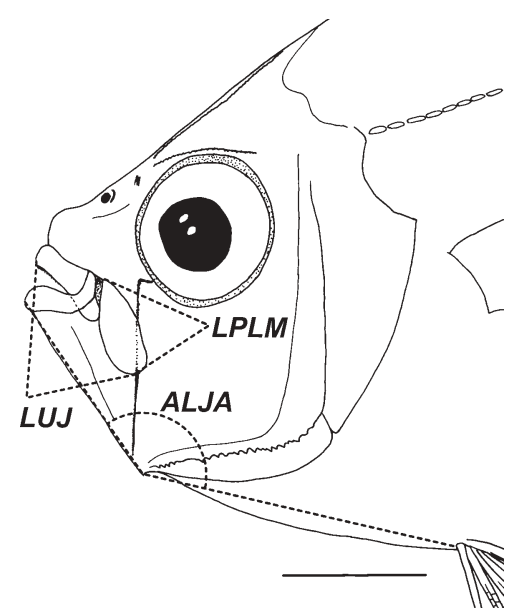

Fig. 1. Measurements of length of upper jaw $(L U J)$, length of posterior limb of maxilla $(L P L M)$, and angle of lower jaw articulation $(A L J A)$. Bar $5 \mathrm{~mm}$

L. hataii exists in the Philippines. Following a critical examination of numerous Leiognathus specimens collected from the Indo-West Pacific, characters diagnostic of L. aureus, $L$. hataii, and the new species have been established. We describe here the new Leiognathus species, and present redescriptions and designate neotypes of L. aureus and L. hataii to clarify the taxonomic status of these fishes and to avoid future confusion. These three species form a complex of morphologically similar leiognathids, which we designate as the "Leiognathus aureus complex."

\section{Materials and Methods}

Counts and measurements generally followed Hubbs and Lagler (1947). Additional measurements included length of posterior limb (exposed portion) of maxilla (Fig. 1), length of lower jaw (anterior tip of lower jaw to lower jaw articulation), snout to pectoral fin insertion (base of uppermost ray), snout to pelvic fin insertion, snout to anal fin origin, pectoral fin insertion to pelvic fin insertion, pelvic fin insertion to anal fin origin, and angle of lower jaw articulation when mouth is closed (the angle formed by tip of lower jaw, lower jaw articulation, and base of pelvic fin spine; Fig. 1). All measurements were made with a digital caliper to the nearest $0.01 \mathrm{~mm}$, except for angle of lower jaw articulation, which was measured by a digital microscope. Cyanine blue was used to examine and count scales. Vertebral counts were made from soft X-ray photos. Standard and head lengths are abbreviated as SL and HL, respectively. Institutional codes follow Leviton et al. (1985) with additional abbreviations as follows: $\mathrm{ABE}$, personal collection of $\mathrm{T}$. Abe; CRDOA, Research Center for Oceanology, Indonesian Institute of Sciences, Jakarta, Indonesia; MUFS, Division of Fisheries Sciences, Faculty of Agriculture, Miyazaki University, Miyazaki, Japan; ZIUT, Zoological Institute of the University of Tokyo, Japan (=ZUMT); ZRC, Raffles

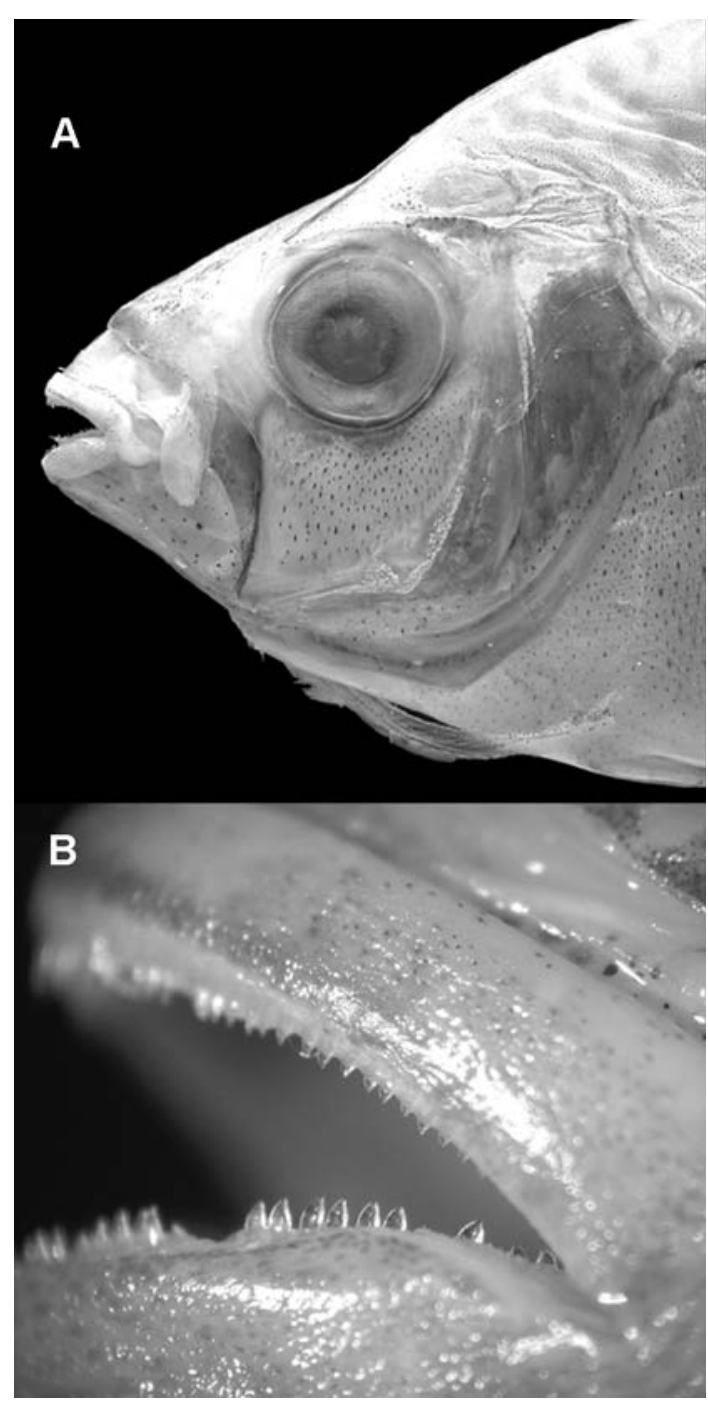

Fig. 2. Head (A) and jaw teeth (B) of Leiognathus aureus, FRLM 29210, $92 \mathrm{~mm} \mathrm{SL}$

Museum of Biodiversity Research, Department of Biological Sciences, National University of Singapore.

\section{The Leiognathus aureus complex}

Leiognathus aureus, L. hataii, and a new species, $L$. panayensis, here defined as the "Leiognathus aureus complex" of the genus Leiognathus from the western Pacific Ocean, are most similar to each other according to the following combination of characters: mouth protruding forward, not downward (Fig. 2A); small but sharp conical teeth uniserially on jaws (Fig. 2B); a black line between the lower margin of the eye and the lower jaw articulation (Fig. 2A); lateral line incomplete, ending below posterior part of dorsal fin base or on anterior caudal peduncle, and sexual dimorphism of the light-organ system, including a larger light organ in males and presence of a male-specific transparent 


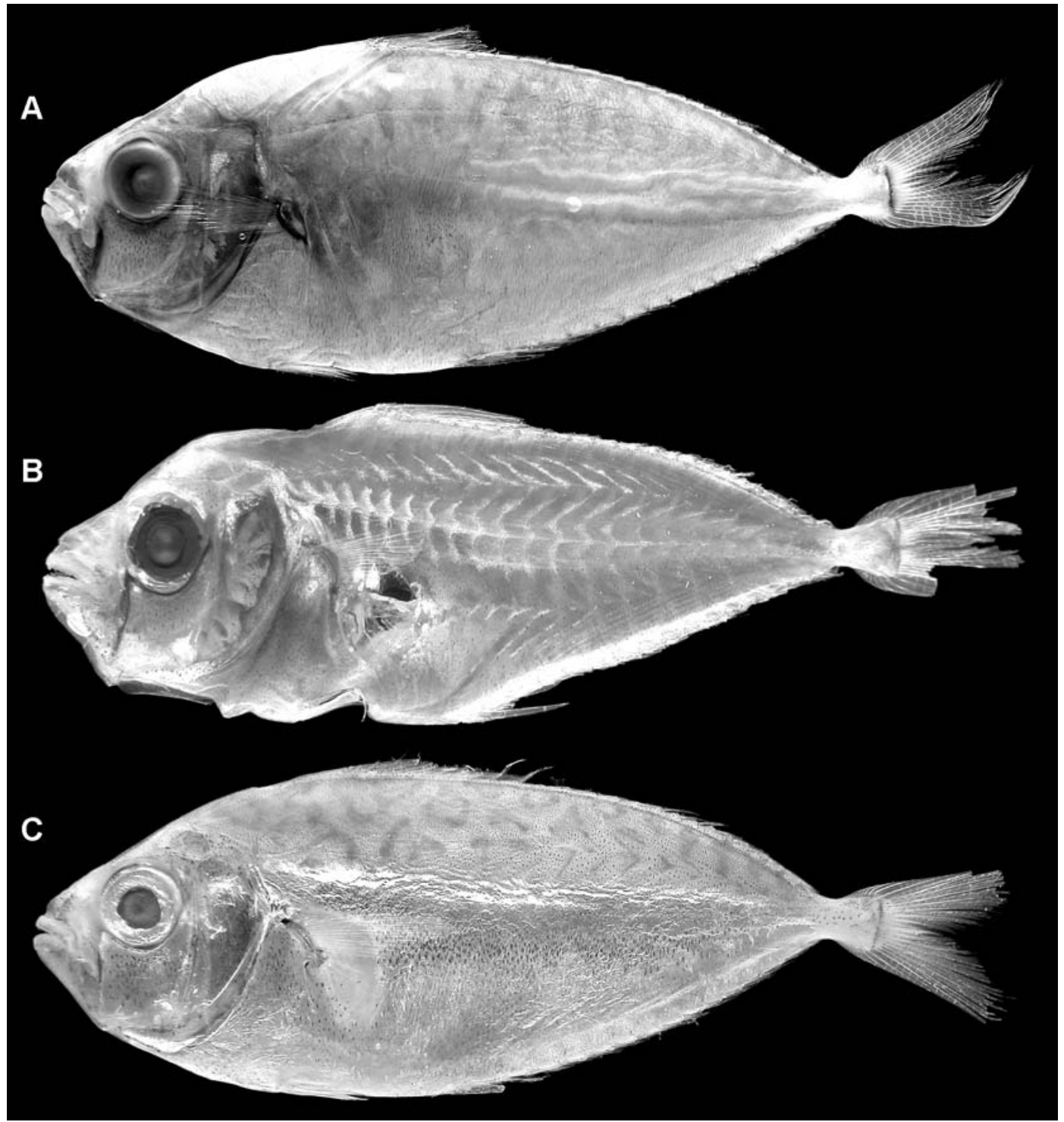

Fig. 3. Leiognathus aureus. A Neotype, YCM-P 35792, $64 \mathrm{~mm}$ SL. B Paratype, YCM-P 35800 (formerly ABE 16076), 47 mm SL. C Non-type material, CSIRO B 2212-1, 71 mm SL, showing dark ringlike markings dorsolateral on body

skin patch just posterior to the pectoral axil. The species belonging to the L. aureus complex are similar in appearance to Gazza species in having a forward-protruding mouth and to Secutor species in having a black membrane between jaws and cheek. However, the species of the present complex are clearly distinguished from Gazza species in lacking canine-like teeth on jaws (large canine-like teeth in Gazza species), and from Secutor species in having a forward-protruding mouth and a single series of small pointed teeth on jaws (an upward-protruding mouth and minute blunt teeth on jaws in Secutor species). Leiognathus bindus (Valenciennes in Cuvier and Valenciennes, 1835) also has a forward-protruding mouth, a single series of small pointed teeth on jaws, and a similar internal and external sexual dimorphism of the light-organ system (McFall-Ngai and Dunlap,1984), but differs from the L. aureus complex in having a disklike body shape, a less dark membrane between jaws and cheek, and a orange blotch on the tip of spinous dorsal fin.

\section{Leiognathus aureus Abe and Haneda, 1972}

(English name: golden ponyfish)

(Fig. 3, Table 1)

Leiognathus aureus Abe and Haneda, 1972: 3-5, pl. 1 (Ambon, North Maluku, Indonesia); Jones, 1985: 571-573 (Timor Sea and Arafura Sea); Mochizuki et al., 1985: 6, pl. 11 (Jakarta, Java, Indonesia, and Ambon, North Maluku, Indonesia); Hutchins, 2001: 33 (Western Australia, listed only); Woodland et al., 2001: 2800, pl. 1 (Banda Sea and Arafura Sea).

Leiognathus sp. cf aureus; Gloerfelt-Tarp and Kailola, 1984: 168-169, 333 (eastward off Siberut Island, off Sumatra, Indonesia). 
Table 1. Counts and measurements of the neotype, paratype, and other specimens of Leiognathus aureus

\begin{tabular}{|c|c|c|c|}
\hline & $\begin{array}{l}\text { Neotype } \\
\text { YCM-P } 35792\end{array}$ & $\begin{array}{l}\text { Paratype } \\
\text { YCM-P } 35800\end{array}$ & Other specimens \\
\hline Standard length (mm) & 64 & 47 & 39-92 $(64.2,47)$ \\
\hline \multicolumn{4}{|l|}{ Counts } \\
\hline Dorsal fin rays & VIII, 16 & VIII, 16 & VIII, 16 (47) \\
\hline Anal fin rays & III, 14 & III, 14 & III, 14 (47) \\
\hline Pectoral fin rays & 18 & 16 & $16-19(17.5,47)$ \\
\hline Pelvic fin rays & $\mathrm{I}, 5$ & $\mathrm{I}, 5$ & I, 5 (47) \\
\hline Lateral line scales & 76 & Damaged & $67-85(75,34)$ \\
\hline Scales above lateral line & 14 & Damaged & $12-18(15.4,42)$ \\
\hline Scales below lateral line & 38 & Damaged & $32-41(36.5,31)$ \\
\hline Gill rakers on upper arch & 5 & 3 & $3-6(4.7,47)$ \\
\hline Gill rakers on lower arch & 16 & 15 & $14-19(16.5,47)$ \\
\hline Vertebrae & $10+14$ & $10+14$ & $10+14(47)$ \\
\hline \multicolumn{4}{|l|}{ Measurements } \\
\hline \multicolumn{4}{|l|}{ As \% of standard length } \\
\hline Head length & 28 & 33 & $26-32(28.5,47)$ \\
\hline Predorsal length & 43 & 43 & $37-44(40.7,47)$ \\
\hline Length of dorsal fin base & 56 & 57 & $53-59(56.1,47)$ \\
\hline Length of anal fin base & 44 & 48 & $42-50(45.9,47)$ \\
\hline Snout to pectoral fin insertion & 29 & 31 & $27-33(30,47)$ \\
\hline Snout to pelvic fin insertion & 33 & 37 & $32-40(35.6,47)$ \\
\hline Snout to anal fin origin & 54 & 53 & $51-57(53.3,47)$ \\
\hline Pectoral fin insertion to pelvic fin insertion & 20 & 19 & $19-24(20.7,47)$ \\
\hline Pelvic fin insertion to anal fin origin & 22 & 19 & $17-31(20.6,47)$ \\
\hline Caudal peduncle length & 10 & 10 & $9-13(10.4,47)$ \\
\hline Body depth & 38 & 37 & $35-45(39.4,47)$ \\
\hline Caudal peduncle depth & 3 & 4 & $4-5(4.4,47)$ \\
\hline \multicolumn{4}{|l|}{ As $\%$ of head length } \\
\hline Snout length & 34 & 30 & $26-35(30.1,47)$ \\
\hline Eye diameter & 36 & 36 & $31-42(36.2,47)$ \\
\hline Upper jaw length & 36 & 34 & $35-43(38.8,47)$ \\
\hline Length of posterior limb of maxilla & 19 & 17 & $15-23(18.9,47)$ \\
\hline Lower jaw length & 39 & 46 & $39-49(44.0,47)$ \\
\hline Interorbital length & 25 & 23 & $22-34(28.5,47)$ \\
\hline Length of 1st dorsal fin spine & 5 & 7 & $5-11(7.9,43)$ \\
\hline Length of 2 nd dorsal fin spine & 44 & 56 & $42-62(49.0,20)$ \\
\hline Length of 3rd dorsal fin spine & Damaged & Damaged & $36-59(43.1,14)$ \\
\hline Length of 1 st anal fin spine & 7 & 9 & $6-11(8.1,42)$ \\
\hline Length of 2 nd anal fin spine & 32 & 35 & $31-45(38.7,21)$ \\
\hline Length of 3 rd anal fin spine & Damaged & Damaged & $24-39(31.6,13)$ \\
\hline Length of pectoral fin & 62 & Damaged & $58-75(68.1,44)$ \\
\hline Length of pelvic fin spine & 30 & Damaged & $24-38(29.5,28)$ \\
\hline Angle of lower jaw articulation $\left(^{\circ}\right)$ & 133 & Damaged & $131-143(137.1,47)$ \\
\hline
\end{tabular}

Figures in parentheses indicate mean values and sample sizes

Leiognathus lineolatus (not of Valenciennes); Shen and Lin, 1985: 136 (Taiwan).

Neotype. YCM-P 35792, $64 \mathrm{~mm}$ SL, female, Ambon fish market, Ambon, North Maluku, Indonesia, 16 Oct. 1969, collected by Y. Haneda.

Paratype. YCM-P 35800 (formerly ABE 16076), 47 mm SL, Ambon fish market, Ambon, North Maluku, Indonesia, 18 Nov. 1969, collected by Y. Haneda (once dried).

Other material. 61 specimens, 39-95 mm SL. AMS I. 21836-003, 3 of 13 specimens, $50-56 \mathrm{~mm}$ SL, Arafura Sea, 15 Nov. 1980, collected by
CSIRO; AMS I. 23034-001, 3 of 9 specimens, 69-75 mm SL, Timor Sea, 30 June 1980, collected by G. Jones; ASIZ 58639, 2 specimens, $57 \mathrm{~mm}$ SL, Tahsi, Taiwan, 15 Sept. 1997, collected by P. Kao; CRDOA 158, $84 \mathrm{~mm}$ SL, Kupang, Timor, Indonesia, date unknown, collected by T. Peristiwady; CRDOA 2608, 79 mm SL, Kupang, Timor, Indonesia, date unknown, collected by T. Peristiwady; CSIRO B 2150, 5 of 30 specimens, 53-62 mm SL, Arafura Sea, 8 July 1980; CSIRO B 2212, 3 of 4 specimens, 59-71 mm SL, Arafura Sea, 15 Nov. 1980; FRLM 2920829209, 2 specimens, 63 mm SL, Baranguay Parara Norte, Tigbauan, Iloilo, Panay Island, Philippines, 27 Mar. 2001, collected by P.V. Dunlap and C.R. Lavilla-Pitogo; FRLM 29210-29212, 3 specimens, 67-92 mm 
SL, Philippines, date unknown, collected by T. Senta; FRLM 29213 29215, 3 specimens, 60-79 mm SL, off Samui Island, Gulf of Thailand, 26 Nov. 1985, collected by K. Mochizuki; NSMT-P 64999, 77 mm SL, Manila Bay, Philippines, 4 Oct. 1995; NSMT-P 64817, 2 specimens, 65 mm SL, same data as FRLM 29208; UMMZ 240307, 4 specimens, 78-84 mm SL, Baranguay Parara Norte, Tigbauan, Iloilo, Panay Island, Philippines, 18 Oct. 2000, collected by P.V. Dunlap and C.R. Lavilla-Pitogo; UMMZ 240308, 72 mm SL, same data as FRLM 29208; UMMZ 240309, 6 specimens, 66-95 mm SL, Baranguay Parara Norte, Tigbauan, Iloilo, Panay, Philippines, 11 Mar. 2002, collected by P.V. Dunlap and C.R. Lavilla-Pitogo (used only for observation of light-organ system); UMMZ 240310, 8 specimens, 75-83 mm SL, Baranguay Parara Norte, Tigbauan, Iloilo, Panay, Philippines, 6 Mar. 2002, collected by P.V. Dunlap and C.R. Lavilla-Pitogo (used only for observation of lightorgan system); YCM-P 6170, 2 specimens, 64 mm SL, Tachi fish market, Taipei, Taiwan, 29 Oct. 1977, collected by M. Hayashi; YCM-P $35793-$ 35799, 7 specimens, 39-62 mm SL, same data as neotype; ZRC 47331, 4 specimens; 53-70 mm SL, Singapore, 22 May 1956.

Diagnosis. A species of Leiognathus as defined by the following characters: mouth protruding forward, not downward; teeth small, slender, pointed, uniserial on jaws; membrane between jaws and cheek densely pigmented, with a black line between anteroventral margin of eye and the lower jaw articulation when mouth closed; lateral line incomplete, ending below base of 12th to 16th dorsal fin soft ray; body rather slender, depth $31-45 \%$ of SL (Fig. 4); posterior limb of maxilla short, $15-23 \%$ of HL (Fig. 4); anteroventral profile of lower jaw straight or slightly convex; lateral line scales 67-85 (Fig. 5); scales above lateral line 12-18 (Fig. 5); scales below lateral line 32-41 (Fig. 5); no large black blotch on nape or below base of dorsal fin spines.

Description. Counts and measurements of the neotype, a paratype, and 46 non-type materials are shown in Table 1. Characters given in diagnosis are not repeated.

Body oblong, somewhat slender, strongly compressed; anterodorsal profile of head straight (including neotype) or slightly concave; interorbital space almost flat; dorsal and ventral profiles of body similarly convex; snout pointed; mouth inclined obliquely upward; posterior limb of maxilla shorter than upper lip, reaching to the vertical through anterior margin of eye; anteroventral profile of lower jaw almost straight (including neotype) or slightly convex; angle of lower jaw articulation blunt; no canine-like teeth on jaws; vomer and palatines toothless; lateral ethmoid bearing a small forked spine on dorsal end, just anterior to supraorbital ridge; supraorbital ridge rugged, with series of minute spines; lower edge of preopercle weakly serrated; two small papillae on rear edge of gill cavity supported by cleithrum, upper less obvious; gill rakers shorter than gill filaments, ca. $1 / 2$ to $3 / 4$ the filament length; scales small, covering most of body except for isthmus to breast; scaled area not reaching to pelvic keel formed by basipterygium nor preanal median keel formed by antrorse extension of first anal fin pterygiophore (Fig. 6A,B); head wholly naked; lateral line ending below base of 12th to 16th (13th in neotype) dorsal fin soft ray; dorsal and anal fin spines slender, weak, compressed; second dorsal and second anal fin spines longest; third and fourth dorsal and third anal fin spines serrated

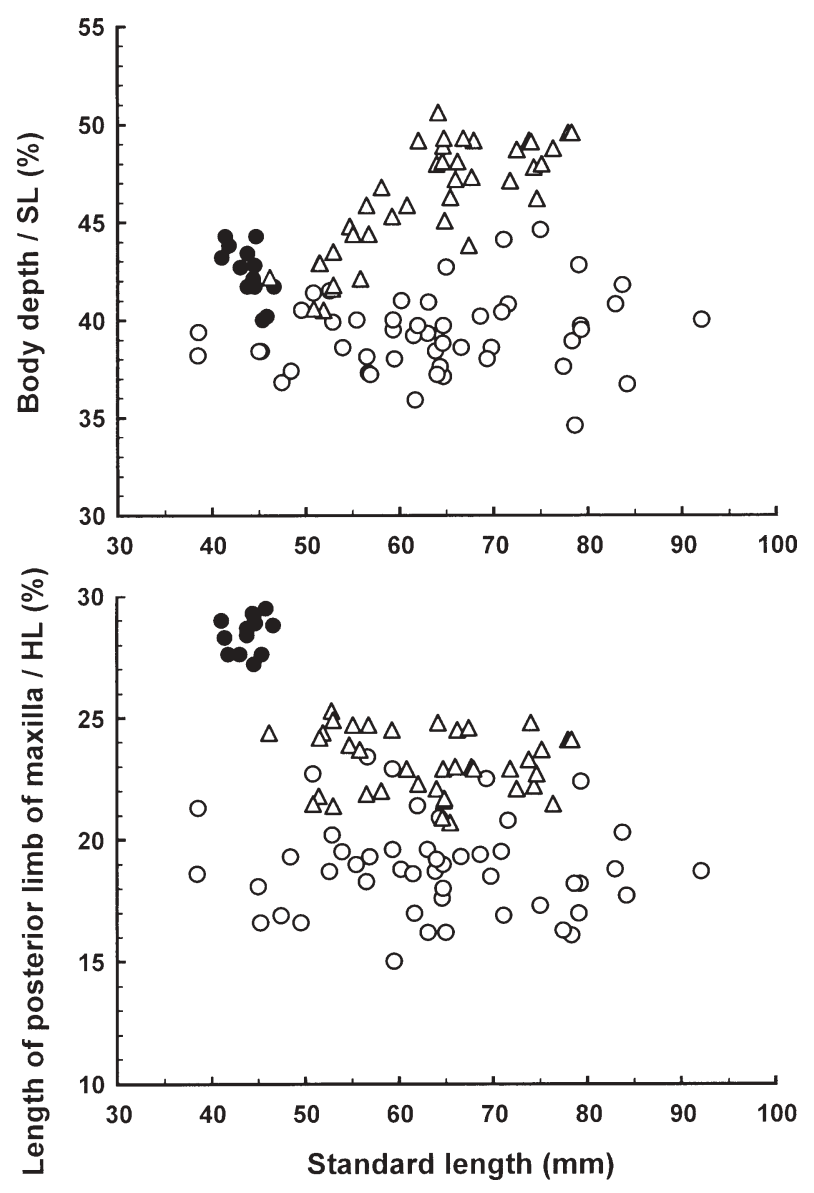

Fig. 4. Proportions of body depth and posterior limb of maxilla in Leiognathus aureus (open circles), L. hataii (solid circles), and L. panayensis sp. nov. (triangles)

proximally along anterior margin; pelvic fins with paired axillary scalelike process; tip of pelvic fin reaching beyond anus, just before (including neotype) or to anterior tip of preanal median keel when appressed; caudal fin forked; tip of neural and hemal spines of fourth preural centrum pointed; first to fourth hypurals forming two plates (first + second and third + fourth); ribs 7 , epipleurals 10 ; a single supraneural; middle pterygiophores of dorsal and anal fin soft rays with pair of exposed retrorse sharp spines on dorsal edge. Maximum recorded length $95 \mathrm{~mm}$ SL (as Leiognathus sp. cf aureus by Gloerfelt-Tarp and Kailola, 1984).

Light-organ system-Light organ "doughnut-like" (Abe and Haneda, 1972); often blocklike or triangular due to varying enlargement of dorsolateral lobes; height $6.0 \mathrm{~mm}$, width $6.2 \mathrm{~mm}$, thickness $2.2 \mathrm{~mm}$ in $84 \mathrm{~mm}$ SL female specimen (UMMZ 240309-1); 3-4 times greater in volume in male specimens (McFall-Ngai and Dunlap, 1984); shiny golden color of portions of outer covering (Abe and Haneda, 1972) distinctive. Males with characteristic beanshaped transparent skin patch immediately posterior to pectoral axil (pectoral axil patch, PAP); PAP absent in females. Dorsolateral lobes of light organ enlarged in males, 

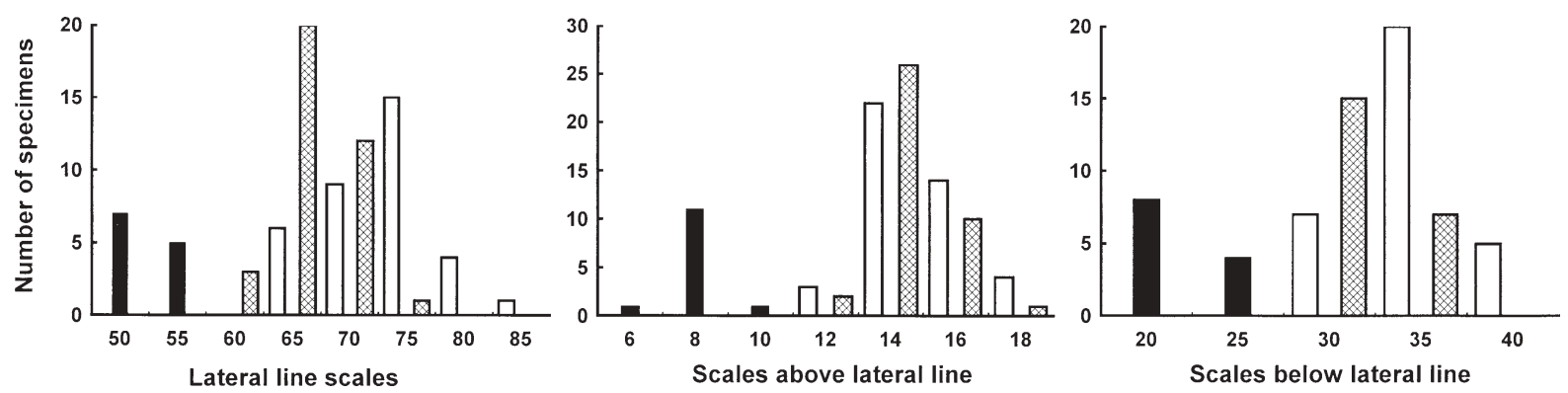

Fig. 5. Frequency distributions of scale counts in Leiognathus aureus (open bars), L. hataii (solid bars), and L. panayensis sp. nov. (crosshatched bars)

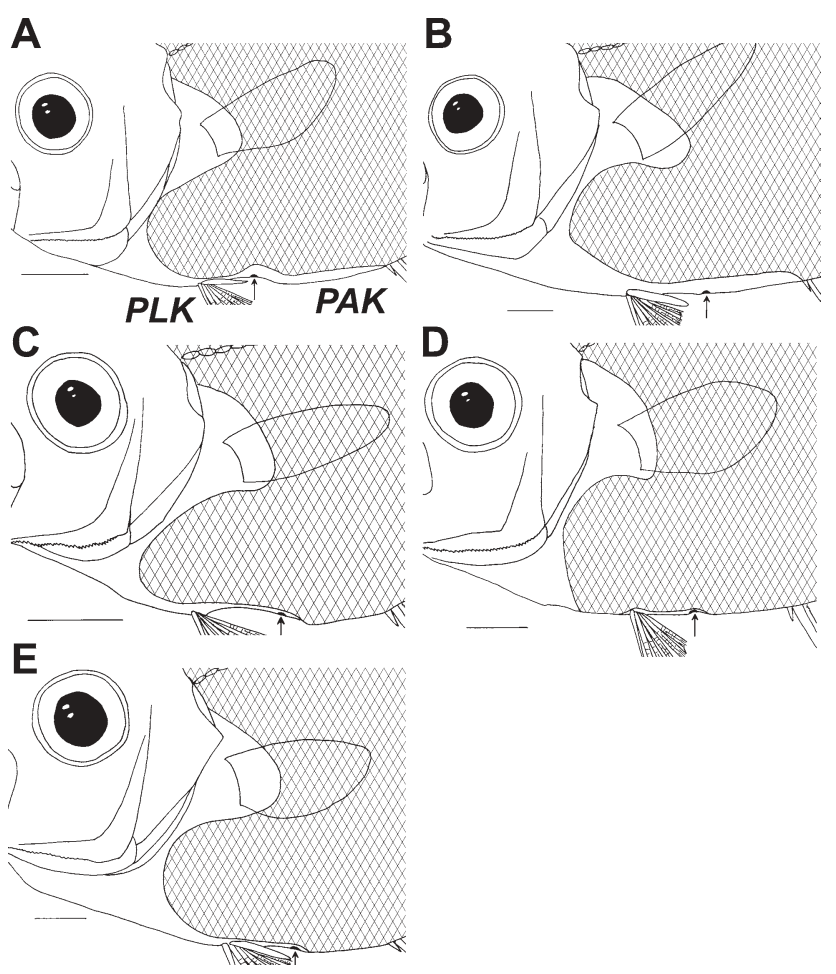

Fig. 6. Anterior part of body; scaled area crosshatched. A Leiognathus aureus, neotype, YCM-P 35792, $64 \mathrm{~mm}$ SL. B Leiognathus aureus, FRLM 29210, 92 mm SL. C Leiognathus hataii, YCM-P 37695-6, 43 mm SL (axillary scalelike process lost) D Leiognathus panayensis sp. nov., holotype, UMMZ 240300, $65 \mathrm{~mm}$ SL (axillary scalelike process lost). E Leiognathus panayensis sp. nov., paratype, FRLM 29203, $78 \mathrm{~mm}$ SL. $P A K$, preanal median keel formed by antrorse extension of first anal pterygiophore; PLK, pelvic keel formed by basipterygium. Arrows, position of anus. Bars $5 \mathrm{~mm}$

abut PAP just posterior to pectoral axils, visible as black spots.

Color of preserved specimens.-Head and body almost uniformly light brown, breast, belly paler; tip of snout dark; rear edge of gill cavity dusky; irregular short dark bands, irregular dark blotches, and usually irregular ringlike dark markings dorsolaterally on body; axil of pectoral fin blackish; bases of dorsal and anal fin soft rays dark, showing dark spots along bases; fins almost colorless.
Distribution. Leiognathus aureus is known from Taiwan, Philippines, Gulf of Thailand, Singapore, Indonesia [Ambon, Sumatra (Gloerfelt-Tarp and Kailola, 1984); Jakarta (Mochizuki et al., 1985), Kupang], Timor Sea, and Arafura Sea.

Remarks. Leiognathus aureus was originally described by Abe and Haneda (1972) based on the holotype (ZIUT 52703, 46.5 mm SL) and five paratypes (ZIUT 52704, ABE 15430, ABE 15431, ABE 16076, and ABE 16077, 46.7-57.0 mm SL) collected from Ambon fish market, Ambon, Indonesia by Y. Haneda. Although it has hitherto been believed that all type materials had been lost [K. Sakamoto (ZUMT), personal communication; searches for the type materials by the first author in ZUMT], T. Yamashita (previous student of FRLM), with the assistance of K. Matsuura (NSMT) and M. Hayashi (YCM), located one paratype, ABE 16076 (presently YCM-P 35800), within the large amount of material extant in Abe's personal collections. Unfortunately, this paratype had been dried out once and is strongly deformed (Fig. 3B). Therefore, identification of the present specimens was made in accordance with the original description, especially with reference to the short posterior limb of the maxilla, the rather slender body, and the irregular vertical bands dorsolaterally on the body (Abe and Haneda, 1972). Jones (1985) redescribed the species based on Australian and Indonesian specimens, incorrectly treating specimens from Haneda's collection from Ambon (YCM-HLP 305) as paratypes. To clarify the taxonomic status of this species and avoid future confusion, we designate here one of Haneda's collections (formerly YCM-HLP 305) as the neotype.

As previously pointed out by Jones (1985), the original description of the lengths of gill rakers (much shorter than gill filaments) is erroneous, gill rakers being $1 / 2$ to $3 / 4$ length of the filaments in all specimens including the specimens collected in Ambon, Indonesia. Moreover, a single forked spine is present on the lateral ethmoid, not two spines as stated in the original description. Although Abe and Haneda (1972) stated "There are about a dozen wavy dark vertical lines on the back; anterior ones are broader than posterior ones," the dorsolateral markings are highly variable, with the vertical lines usually changing to irregular blotches or ringlike markings (Fig. 3A,C). Leiognathus sp. cf. aureus sensu Gloerfelt-Tarp and Kailola (1984) shows such dark ringlike markings dorsolaterally on the body, this fish 


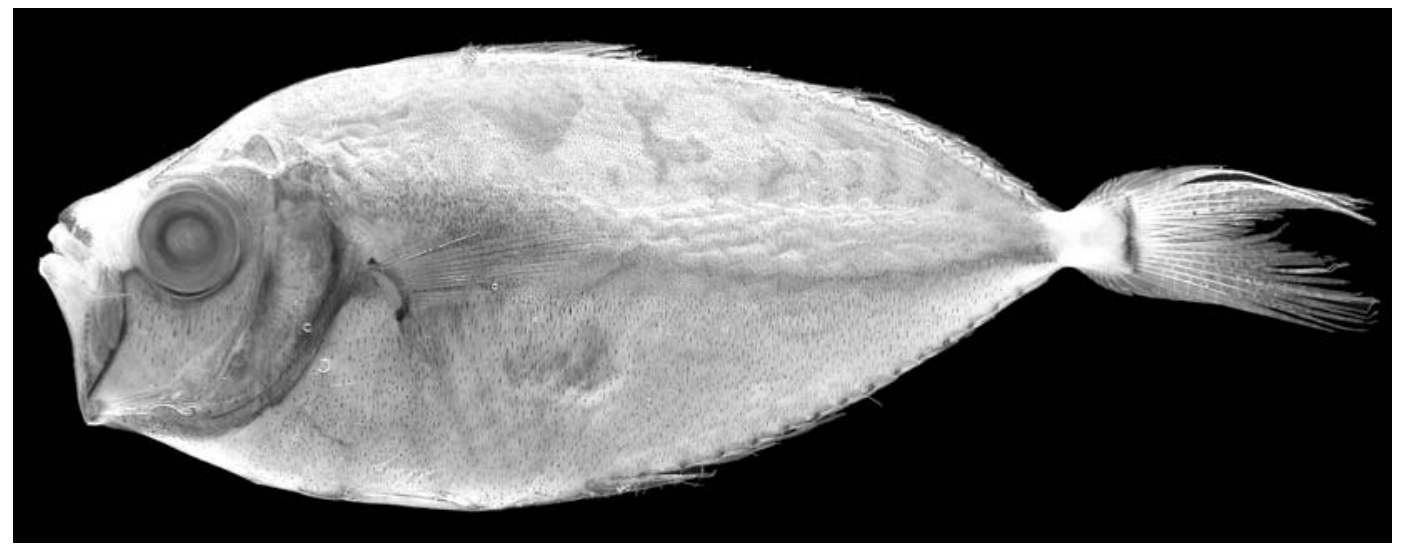

Fig. 7. Neotype of Leiognathus hataii, YCM-P 37696, $47 \mathrm{~mm} \mathrm{SL}$

undoubtedly being conspecific with L. aureus. Shen and Lin's (1985) "Leiognathus lineolatus" is also identifiable with L. aureus on the basis of its photograph (Shen and Lin, 1985: fig. 12).

Comparison. Leiognathus aureus is easily distinguished from L. hatai in lacking a large dark blotch below the spinous dorsal fin base and larger counts of scales (lateral line scales $67-85$ vs. 50-58 in the latter; scales above lateral line $12-18$ vs. $7-10$; scales below lateral line $32-41$ vs. $22-26$; Fig. 5). Leiognathus aureus also resembles L. panayensis sp. nov. in general body appearance and counts, but the former is distinguishable from the latter in having a more slender body (body depth $35-45 \%$ SL vs. $41-51 \%$ SL in the latter; Fig. 4), a shorter posterior limb of the maxilla (15-23\% HL vs. $21-25 \%$ HL; Fig. 4), belly naked along midventral area (vs. wholly scaled; Fig. 6), and no dark blotch on the nape (vs. present).

\section{Leiognathus hataii Abe and Haneda, 1972 (New English name: Hatai's ponyfish)}

(Fig. 7, Table 2)

Leiognathus hataii Abe and Haneda, 1972: 1-3, pl. 1 (Ambon, North Maluku, Indonesia); Woodland et al., 2001: 2796 (Western Central Pacific, listed only).

Neotype. YCM-P 37696, $47 \mathrm{~mm}$ SL, female, Ambon fish market, Ambon, North Maluku, Indonesia, 16 Oct. 1969, collected by Y. Haneda.

Other material. 12 specimens, 41-46 mm SL. YCM-P 37693, 4 specimens, 41-45 mm SL, same data as neotype; YCM-P 37694, 46 mm SL, same data as neotype; YCM-P 37693, 4 specimens, 41-45 mm SL, same data as neotype; YCM-P 37694, 46 mm SL, same data as neotype; YCMP 37695, 6 specimens, 42-45 mm SL, same data as neotype; YCM-P 37693, 4 specimens, 41-45 mm SL, same data as neotype; YCM-P 37697 , $41 \mathrm{~mm}$ SL, same data as neotype.

Diagnosis. A species of Leiognathus as defined by the following characters: mouth protruding forward, not downward; teeth small, slender, pointed, uniserial on jaws; membrane between jaws and cheek densely pigmented, with a black line between anteroventral margin of eye and the lower jaw articulation when mouth closed; lateral line incomplete, ending below base of 11th to 15th dorsal fin soft ray; body rather deep, 40-44\% of SL (Fig. 4); posterior limb of maxilla very long, 27-30\% of HL (Fig. 4); anteroventral profile of lower jaw concave; lateral line scales 50-58 (Fig. 5); scales above lateral line 7-10 (Fig. 5); scales below lateral line 22-26 (Fig. 5); large black blotch below base of dorsal fin spine.

Description. Counts and measurements of the neotype and 12 non-type materials are shown in Table 2. Characters given in diagnosis are not repeated.

Body oblong, strongly compressed; anterodorsal profile of head concave; interorbital space convex; dorsal profile of body less convex than ventral profile; snout pointed; mouth inclined obliquely upward; posterior limb of maxilla almost same length as upper lip, reaching to or slightly beyond (including neotype) the vertical through anterior margin of eye; angle of lower jaw articulation sharp, rather pointed; a single series of small, slender, pointed teeth in both jaws; no canine-like teeth on jaws; vomer and palatines toothless; lateral ethmoid bearing a small forked spine on dorsal end, just anterior to supraorbital ridge; supraorbital ridge rugged, with series of small but robust spines; lower edge of preopercle with fine serrations; two small papillae on rear edge of gill cavity supported by cleithrum, upper less obvious; gill rakers shorter than gill filaments, ca. $1 / 2$ to $3 / 4$ the filament length; scales somewhat large, covering most of body except for isthmus to ventral surface of breast and base of pectoral fin; head wholly naked; lateral line ending below base of 11th to 15th (13th in neotype) dorsal fin soft ray; dorsal and anal fin spines slender, weak, compressed; second dorsal and second anal fin spines longest; third and fourth dorsal and third anal fin spines serrated proximally along anterior margin; pelvic fins with paired axillary scalelike process; tip of pelvic fin reaching beyond anus, just before or to anterior tip of preanal median keel (including holotype) when appressed; caudal fin forked; tip of neural and hemal spines of fourth preural centrum pointed; first to fourth hypurals forming two plates (first + second and third + fourth); ribs 7, epipleurals 10; a single supraneural; 
Table 2. Counts and measurements of the neotype and other specimens of Leiognathus hataii

\begin{tabular}{|c|c|c|}
\hline & $\begin{array}{l}\text { Neotype } \\
\text { YCM-P } 37696\end{array}$ & Other specimens \\
\hline Standard length (mm) & 47 & $41-46(43.7,12)$ \\
\hline \multicolumn{3}{|l|}{ Counts } \\
\hline Dorsal fin rays & VIII, 16 & VIII, 16 (12) \\
\hline Anal fin rays & III, 14 & III, 14 (12) \\
\hline Pectoral fin rays & 16 & $15-16(15.8,12)$ \\
\hline Pelvic fin rays & $\mathrm{I}, 5$ & I, 5 (12) \\
\hline Lateral line scales & 57 & $50-58(53.8,11)$ \\
\hline Scales above lateral line & 8 & $7-10(8.5,12)$ \\
\hline Scales below lateral line & 24 & $22-26(23.6,11)$ \\
\hline Gill rakers on upper arch & 4 & $4-5(4.3,12)$ \\
\hline Gill rakers on lower arch & 16 & $14-16(15.2,12)$ \\
\hline Vertebrae & $10+14$ & $10+14(12)$ \\
\hline \multicolumn{3}{|l|}{ Measurements } \\
\hline \multicolumn{3}{|l|}{ As $\%$ of standard length } \\
\hline Head length & 30 & $28-31(29.9,12)$ \\
\hline Predorsal length & 42 & $42-45(43.9,12)$ \\
\hline Length of dorsal fin base & 55 & $50-55(53.2,12)$ \\
\hline Length of anal fin base & 44 & $43-46(44.4,12)$ \\
\hline Snout to pectoral fin insertion & 31 & $29-33(31.1,12)$ \\
\hline Snout to pelvic fin insertion & 36 & $34-37(35.9,12)$ \\
\hline Snout to anal fin origin & 55 & $52-57(55.0,12)$ \\
\hline Pectoral fin insertion to pelvic fin insertion & 22 & $22-23(22.4,12)$ \\
\hline Pelvic fin insertion to anal fin origin & 20 & $21-28(23.4,12)$ \\
\hline Caudal peduncle length & 11 & $10-13(10.8,12)$ \\
\hline Body depth & 42 & $40-44(42.5,12)$ \\
\hline Caudal peduncle depth & 5 & $4-5(4.5,12)$ \\
\hline \multicolumn{3}{|l|}{ As \% of head length } \\
\hline Snout length & 31 & $28-38(32.5,12)$ \\
\hline Eye diameter & 37 & $34-43(38.4,12)$ \\
\hline Upper jaw length & 46 & $43-50(46.7,12)$ \\
\hline Length of posterior limb of maxilla & 29 & $27-30(28.4,12)$ \\
\hline Lower jaw length & 49 & $47-55(51.1,12)$ \\
\hline Interorbital length & 23 & $23-32(27.5,12)$ \\
\hline Length of 1st dorsal fin spine & 7 & $6-10(7.2,12)$ \\
\hline Length of 2 nd dorsal fin spine & 45 & $46-51(48.1,12)$ \\
\hline Length of 3rd dorsal fin spine & 43 & $39-49(43.8,9)$ \\
\hline Length of 1 st anal fin spine & 11 & $6-13(9.5,11)$ \\
\hline Length of 2 nd anal fin spine & 31 & $31-39(34.6,12)$ \\
\hline Length of $3 \mathrm{rd}$ anal fin spine & 25 & $26-32(28.4,5)$ \\
\hline Length of pectoral fin & 73 & $73-79(75.8,12)$ \\
\hline Length of pelvic fin spine & 35 & $35-37(36.2,3)$ \\
\hline Angle of lower jaw articulation $\left(^{\circ}\right)$ & 122 & $110-122(117.6,12)$ \\
\hline
\end{tabular}

Figures in parentheses indicate mean values and sample sizes

middle pterygiophores of dorsal and anal fin soft rays with pair of exposed retrorse sharp spines on dorsal edge. Maximum recorded length $48 \mathrm{~mm}$ SL (holotype described by Abe and Haneda, 1972).

Light-organ system.- - Light organ similar in overall morphology, size, and appearance to that of L. aureus, including golden color of portions of light-organ outer covering (Abe and Haneda, 1972); gold color no longer apparent in preserved specimens examined here; somewhat blocklike or triangular due to enlargement of dorsolateral lobes; propor- tionally more narrow and elongate dorsoventrally and less robust dorsolaterally than in L. panayensis sp. nov.; height $4.7 \mathrm{~mm}$, width $3.3 \mathrm{~mm}$, thickness $1.5 \mathrm{~mm}$ in $45 \mathrm{~mm}$ SL female specimen (YCM-P 37695-4); height $4.9 \mathrm{~mm}$, width, $4.7 \mathrm{~mm}$, thickness $2.5 \mathrm{~mm}$ in $44 \mathrm{~mm}$ SL male specimen (YCM-P 37695-2) (i.e., approximately 2.5 fold greater in male). Greater size of male light organ largely due to more strongly enlarged dorsolateral lobes, which abut flank internally just posterior of pectoral fin axil and are visible as black spots. Males with bean-shaped transparent skin PAP; 


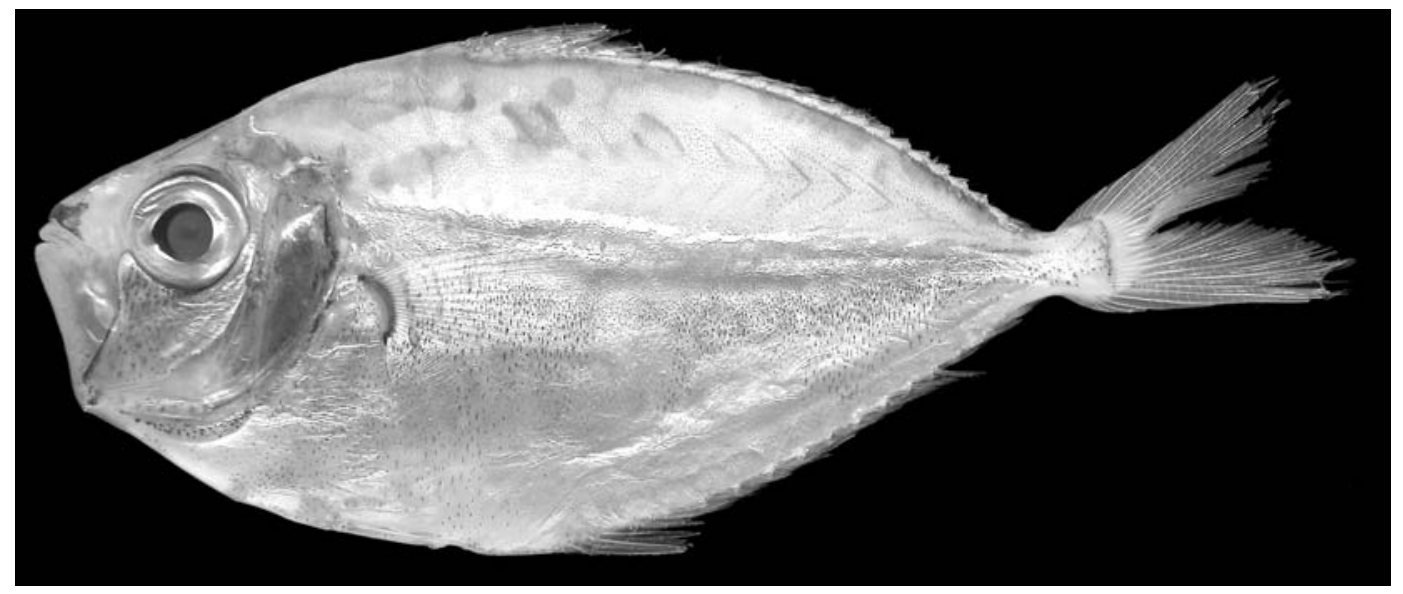

Fig. 8. Leiognathus panayensis sp. nov., holotype, UMMZ 240300, 65 mm SL

PAP as in male L. aureus; but substantially smaller; similar in shape and size to that in male L. panayensis sp. nov., absent in female L. hataii. These observations establish sexual dimorphism of the light-organ system of L. hataii.

Color of preserved specimens.-Head and body almost uniformly light brown; breast, belly, and caudal peduncle paler; tip of snout dark; membrane between jaws and cheek densely pigmented, showing a black line between anteroventral margin of eye and lower jaw articulation when mouth closed; rear edge of gill cavity dusky; irregular dark blotches dorsolaterally on body, larger blotches on nape (often faded) and below spinous portion of dorsal fin; axil of pectoral fin blackish; caudal fin base dark, showing a black vertical line; bases of dorsal and anal fin soft rays dark, showing dark spots along bases; upper dorsal fin membranes between second and fourth spines dark; both lobes of caudal fin dusky; other fins colorless.

Distribution. Leiognathus hataii is known only from Ambon, North Maluku, Indonesia (Abe and Haneda, 1972; this study).

Remarks. Leiognathus hataii was described originally by Abe and Haneda (1972) based on the holotype (ZIUT 52701, $48 \mathrm{~mm} \mathrm{SL}$ ) and three paratypes (ZIUT 52702, ABE 15428, and ABE 15429, 42.5-44.0 mm SL) collected from Ambon fish market, Ambon, Indonesia by Y. Haneda. However, careful searches for the type material at ZUMT (K. Sakamoto, personal communication) and by one of us (S.K.) at ZUMT and among the extant ABE specimens convince us that all type materials have been lost. Identification of the present specimens therefore was made in accordance with the original description, especially with reference to the long posterior limb of maxilla and dark blotches on nape and below base of spinous portion of dorsal fin (Abe and Haneda, 1972: figs. 1 and 2). Apart from the types, specimens of L. hataii collected from Ambon by Y. Haneda on 16 Oct. 1969 have been kept in YCM in two lots mixed with $L$. aureus. To clarify the taxonomic status of this fish and to avoid future confusion, one of those specimens is designated here as the neotype.
Comparison. Leiognathus hataii is distinguished from both L. aureus and L. panayensis sp. nov. in having a large dark blotch below the spinous dorsal fin base and fewer counts of scales (lateral line scales $50-58$ vs. $64-85$ in the latter two species; scales above lateral line 7-10 vs. 12-18; scales below lateral line 22-26 vs. 30-41; Fig. 5).

\section{Leiognathus panayensis sp. nov. Kimura and Dunlap \\ (New English name: Panay ponyfish)}

(Fig. 8, Table 3)

Holotype. UMMZ 240300, $65 \mathrm{~mm}$ SL, female, Baranguay Parara Norte, Tigbauan, Iloilo, Panay Island, Philippines, 27 Mar. 2001, collected by P.V. Dunlap and C.R. Lavilla-Pitogo.

Paratypes. 64 specimens, 46-83 mm SL. AMS I. 41699-001, 2 specimens, 64-74 mm SL, Baranguay Parara Norte, Tigbauan, Iloilo, Panay Island, Philippines, 18 Oct. 2000, collected by P.V. Dunlap and C.R. Lavilla-Pitogo; BMNH 2002.10.1.1-2, 2 specimens, 65-76mm SL, Baranguay Parara Norte, Tigbauan, Iloilo, Panay Island, Philippines, 10 July 2001, collected by P.V. Dunlap and C.R. Lavilla-Pitogo; FRLM 29199, 65 mm SL, Baranguay Parara Norte, Tigbauan, Iloilo, Panay Island, Philippines, 20 July 2000, collected by P.V. Dunlap and C.R. Lavilla-Pitogo; FRLM 29200-292001, 2 specimens, 74 mm SL, same data as AMS I. 41699-001; FRLM 29202-292006, 5 specimens, 46-78 mm SL, same data as holotype; FRLM 29207, $67 \mathrm{~mm}$ SL, Iloilo, Panay Island, Philippines, date unknown, collected by T. Senta; MNHN 2002-3320, 2002-3321, 2 specimens, 59-67 mm SL, same data as BMNH 2002.10.1.1-2; MUFS 21943, $65 \mathrm{~mm}$ SL, same data as FRLM 29200; NSMT-P 64816, 64 mm SL, same data as FRLM 29199; NSMT-P 64817, $72 \mathrm{~mm}$ SL, same data as holotype; UMMZ 240301, 4 specimens, 64-83 mm SL, same data as FRLM 29199 (3 of 4 used only for observation of light-organ system); UMMZ 240302, 5 specimens, 65-75 mm SL, same data as AMS I. 41699-001 (used only for observation of lightorgan system); UMMZ 240303, 8 specimens, 49-82 mm SL, same data as the holotype ( 7 of 8 used only for observation of light-organ system); UMMZ 240304, 16 specimens, 47-76 mm SL, same data as BMNH 2002.10.1.1-2 (10 of 16 used only for observation of light-organ system); USNM 371378, 2 specimens, 66-68 mm SL, same data as holotype; 
Table 3. Counts and measurements of the holotype and paratypes of Leiognathus panayensis sp. nov.

\begin{tabular}{|c|c|c|}
\hline & $\begin{array}{l}\text { Holotype } \\
\text { UMMZ } 240300\end{array}$ & Paratypes \\
\hline Standard length (mm) & 65 & $46-78(63.3,39)$ \\
\hline \multicolumn{3}{|l|}{ Counts } \\
\hline Dorsal fin rays & VIII, 16 & VIII, 16 (39) \\
\hline Anal fin rays & III, 14 & III, 14 (39) \\
\hline Pectoral fin rays & 17 & $16-18(16.8,38)$ \\
\hline Pelvic fin rays & $\mathrm{I}, 5$ & I, $5(39)$ \\
\hline Lateral line scales & 68 & $64-75(68.7,35)$ \\
\hline Scales above lateral line & 14 & $13-18(15.1,38)$ \\
\hline Scales below lateral line & 34 & $30-37(33.7,21)$ \\
\hline Gill rakers on upper arch & 5 & $3-6(4.4,39)$ \\
\hline Gill rakers on lower arch & 17 & $15-18(16.8,39)$ \\
\hline Vertebrae & $10+14$ & $10+14(39)$ \\
\hline \multicolumn{3}{|l|}{ Measurements } \\
\hline \multicolumn{3}{|l|}{ As $\%$ of standard length } \\
\hline Head length & 29 & $27-32(29.7,39)$ \\
\hline Predorsal length & 44 & $40-46(43.0,39)$ \\
\hline Length of dorsal fin base & 56 & $52-59(54.7,38)$ \\
\hline Length of anal fin base & 46 & $44-49(46.0,36)$ \\
\hline Snout to pectoral fin insertion & 32 & $30-34(31.3,39)$ \\
\hline Snout to pelvic fin insertion & 39 & $34-45(38.8,39)$ \\
\hline Snout to anal fin origin & 57 & $51-60(55.9,35)$ \\
\hline Pectoral fin insertion to pelvic fin insertion & 24 & $21-29(23.3,39)$ \\
\hline Pelvic fin insertion to anal fin origin & 21 & $18-24(20.7,34)$ \\
\hline Caudal peduncle length & 11 & $8-13(10.5,39)$ \\
\hline Body depth & 49 & $41-51(46.2,39)$ \\
\hline Caudal peduncle depth & 5 & $5-6(5.3,39)$ \\
\hline \multicolumn{3}{|l|}{ As $\%$ of head length } \\
\hline Snout length & 32 & $25-36(29.9,39)$ \\
\hline Eye diameter & 40 & $36-43(39.5,39)$ \\
\hline Upper jaw length & 45 & $38-51(43.4,38)$ \\
\hline Length of posterior limb of maxilla & 23 & $21-25(23.2,38)$ \\
\hline Lower jaw length & 48 & $41-56(47.7,39)$ \\
\hline Interorbital length & 32 & $26-36(30.2,39)$ \\
\hline Length of 1st dorsal fin spine & 11 & $5-12(8.7,33)$ \\
\hline Length of 2nd dorsal fin spine & Damaged & $45-60(51.0,17)$ \\
\hline Length of 3rd dorsal fin spine & Damaged & $36-51(43.7,16)$ \\
\hline Length of 1 st anal fin spine & 12 & $6-14(9.5,33)$ \\
\hline Length of 2 nd anal fin spine & 41 & $32-47(39.2,26)$ \\
\hline Length of $3 \mathrm{rd}$ anal fin spine & 34 & $27-38(32.4,17)$ \\
\hline Length of pectoral fin & 79 & $49-80(68.8,36)$ \\
\hline Length of pelvic fin spine & 36 & $21-40(33.5,38)$ \\
\hline Angle of lower jaw articulation $\left(^{\circ}\right)$ & 132 & $124-139(127.8,38)$ \\
\hline
\end{tabular}

Figures in parentheses indicate mean values and sample sizes

YCM-P 37682, 53 mm SL, Iloilo, Panay Island, Philippines, 18 Feb. 1981, collected by Y. Haneda; YCM-P 37683-37692, 10 specimens, 51-57 mm SL, Philippines, 11 Feb. 1981, collected by Y. Haneda.

Diagnosis. A species of Leiognathus as defined by the following characters: mouth protruding forward, not downward; teeth small, slender, pointed, uniserial on jaws; membrane between jaws and cheek densely pigmented, with a black line between anteroventral margin of eye and the lower jaw articulation when mouth closed; lateral line in- complete, ending below base of 14th to 16th dorsal fin soft ray or at anterior caudal peduncle; body deep, $41-51 \%$ of SL (Fig. 4); posterior limb of maxilla long, $21-26 \%$ of HL (Fig. 4); anteroventral profile of lower jaw slightly concave; lateral line scales 64-75 (Fig. 5); scales above lateral line 13-18 (Fig. 5); scales below lateral line 30-37 (Fig. 5); belly almost wholly scaled (Fig. 6); large black blotch on nape.

Description. Counts and measurements of the holotype and 39 paratypes are shown in Table 3. Characters given in diagnosis are not repeated. 
Body deep, ovoid, strongly compressed, proportion of body depth to SL increasing with growth (Fig. 4); anterodorsal profile of head straight (including holotype) or slightly concave; interorbital space convex; dorsal and anal profiles of body similarly convex; snout pointed; mouth inclined obliquely upward; posterior limb of maxilla almost same length as upper lip, reaching to the vertical through anterior margin of eye; angle of lower jaw articulation moderate; no canine-like teeth on jaws; vomer and palatines toothless; lateral ethmoid bearing a small forked spine on dorsal end, just anterior to supraorbital ridge; supraorbital ridge rugged, with series of small spines; lower edge of preopercle with fine serrations; two small papillae on rear edge of gill cavity supported by cleithrum, upper less obvious in smaller specimens; gill rakers shorter than gill filaments, ca. $1 / 2$ to $3 / 4$ the filament length; scales small, covering most of body except for isthmus to breast (Fig. $6 \mathrm{D}, \mathrm{E}$ ); scaled area reaching to pelvic keel (including holotype, Fig. 6D) or not (Fig. 6E), but reaching to preanal median keel in all specimens; head wholly naked; lateral line ending below base of 14th to 16th (16th in holotype) dorsal fin soft ray or on anterior caudal peduncle just behind base of last dorsal fin soft ray; dorsal and anal fin spines slender, weak, compressed; second dorsal and second anal fin spines longest; third and forth dorsal and third anal fin spines serrated proximally along anterior margin; pelvic fins with paired axillary scalelike process; tip of pelvic fin reaching beyond anus, just before or to anterior tip of preanal median keel (including holotype) when appressed; caudal fin forked; tip of neural and hemal spines of fourth preural centrum pointed; first to fourth hypurals forming two plates (first + second and third + fourth); ribs 7, epipleurals, 10; a single supraneural; middle pterygiophores of dorsal and anal fin soft rays with pair of exposed retrorse sharp spines on dorsal edge. Maximum recorded length $83 \mathrm{~mm}$ SL.

Light-organ system. - Light organ similar in overall morphology to that of L. aureus (see Abe and Haneda, 1972; McFall-Ngai and Dunlap, 1984; this study); height $4.3 \mathrm{~mm}$, width $5.0 \mathrm{~mm}$, thickness $3.0 \mathrm{~mm}$ in $64 \mathrm{~mm}$ SL female specimen (UMMZ 240302-1); height $5.9 \mathrm{~mm}$, width $6.8 \mathrm{~mm}$, thickness, $3.9 \mathrm{~mm}$ in $65 \mathrm{~mm}$ SL male specimen (UMMZ 240302-2) (i.e., approximately 1.5-2.5 times larger in male). Males with bean-shaped transparent PAP, located similarly in L. aureus but smaller, extending less to the ventral and posterior; PAP absent in females. Dorsolateral lobes of light organ enlarged in males, abut PAP just posterior to pectoral axils, visible as black spots. These observations establish sexual dimorphism of the light-organ system of $L$. panayensis sp. nov., and they indicate the presence of substantial similarities among the members of the L. aureus complex in light-organ morphology and sexual dimorphism of the light-organ system.

Color of preserved specimens.-Head and body almost uniformly light brown, breast, belly, and caudal peduncle paler; tip of snout dark; rear edge of gill cavity dusky; irregular dark blotches dorsolaterally on body; axil of pectoral fin blackish; caudal fin base dark, showing a black vertical line; bases of dorsal and anal fin soft rays dark; upper dorsal fin membranes between second and fourth spines dark; other fins colorless.

Distribution. Leiognathus panayensis sp. nov. is known only from the Philippines, mainly from Panay Island.

Etymology. The specific name "panayensis" is named after the type locality of the species.

Comparisons. Leiognathus panayensis sp. nov. is most similar to $L$. hataii in general body appearance and scalation. However, it differs from the latter in having larger scale counts (lateral line scales $64-75$ vs. $50-58$ in the latter; scales above lateral line $13-18$ vs. $7-10$; scales below lateral line 30-37 vs. 22-26; Fig. 5) and in lacking a large dark blotch below the spinous dorsal fin base (present in the latter). A comparison with $L$. aureus has been given above.

Acknowledgments We are deeply indebted to K. Mochizuki (Natural History Museum and Institute, Chiba, Japan) and T. Yoshino (URM) for providing critical support to S.K. for the study of leiognathids, to M. Hayashi (YCM) and K. Matsuura (NSMT) for opportunities to examine Haneda's and Abe's collections, and to K. Sakamoto (ZUMT) for providing important information on the types of Leiognathus aureus and L. hataii. J. Ledesma (Tigbauan, Iloilo, Philippines) provided invaluable assistance in the collection of fish. We are grateful to the following persons and institutions for specimen loans: M. McGrouther (AMS); K.-T. Shao (ASIZ); J. Maclaine (BMNH); A. Graham (CSIRO); Y. Iwatsuki (MUFS); G. Shinohara (NSMT); D.W. Nelson (UMMZ); J.M. Clayton (USNM), and P.K.L. Ng and K.K.P. Lim (ZRC). We also thank T. Yamashita and T. Ito (previous students of FRLM) for their help in examination of Abe's collection. This study was supported in part by Grants-in-Aid for Scientific Research (C) awarded to S.K. by the Grant-in-Aid for Scientific Research (C) of the Japan Society for the Promotion of Science (14540642), by the Core University Program of the Japan Society for the Promotion of Science (Biodiversity Studies in the coastal areas of South East Asia), and by a grant to P.V.D. from the University of Michigan Center for Japanese Studies.

\section{Literature Cited}

Abe T, Haneda Y (1972) Description of two new species of the ponyfish genus Leiognathus from Indonesia. Sci Rep Yokosuka City Mus 19:1-6, pl 1

Cuvier G, Valenciennes A (1835) Histoire naturelle des poissons, vol 10. F.G. Levrault, Paris

Gistel J (1848) Naturgeschichte des Thierreichs, für höhere Schulen. Thierreichs, Stuttgart

Gloerfelt-Tarp T, Kailola PJ (1984) Trawled fishes of southern Indonesia and northwestern Australia. Australian Development Assistance Bureau (ADAB), Directorate General of Fisheries, Indonesia (DGF), and German Agency for Technical Cooperation (GTZ)

Hubbs CL, Lagler JF (1947) Fishes of the Great Lakes region. Bull Cranbrook Inst Sci 26:1-186

Hutchins JB (2001) Checklist of the fishes of West Australia. Rec West Aust Mus Suppl 63:9-50

James PSBR (1975) A systematic review of the fishes of the family Leiognathidae. J Mar Biol Assoc India 17:138-172

James PSBR (1984) Leiognathidae. In: Fischer W, Bianchi G (eds) FAO species identification sheets for fishery purposes. Western Indian Ocean (fishing area 51), vol 2. FAO, Rome, pp "Leiog”-“Leiog Sec 2" Jones G (1985) Revision of the Australian species of the fish family Leiognathidae. Aust J Mar Freshw Res 36:559-613 
Kimura S, Peristiwady T (2000) Leiognathidae. In: Matsuura K, Sumadhiharga OK, Tsukamoto K (eds) Field guide to Lombok Island. Ocean Research Institute, University of Tokyo, Tokyo, pp 210-229

Kimura S, Yamashita T, Iwatsuki Y (2000) A new species, Gazza rhombea, from the Indo-West Pacific, with a redescription of $G$. achlamys Jordan \& Starks, 1917 (Perciformes: Leiognathidae). Ichthyol Res 47:1-12

Lacepéde BGE (1802) Histoire naturelle des poisons, vol 4. Plasson, Paris

Leviton AE, Gibbs RH Jr, Heal E, Dawson CE (1985) Standards in herpetology and ichthyology. Part 1 . Standard symbolic codes for institutional resource collections in herpetology and ichthyology. Copeia 1985:802-832

McFall-Ngai MJ, Dunlap PV (1984) External and internal sexual dimorphism in leiognathid fishes: morphological evidence for sexspecific bioluminescent signalling. J Morphol 182:71-83

Mochizuki K, Hayashi M (1989) Revision of the leiognathid fishes of the genus Scutor, with two new species. Sci Rep Yokosuka City Mus 37:83-95

Mochizuki K, Aizawa M, Hayashi M (1985) The catalogue of luminous organisms collection in the Yokosuka City Museum (II) (Class:
Chondrichthyes and Osteichthyes). Misc Rep Yokosuka City Mus 9:1-15

Rüppell E (1835) Neue wirbelthiere zu der Fauna von Abyssinien gehörig, entdeckt und beschrieben, vol 1. Commission bei Siegmund Schmerber, Frankfurt am Main

Shen SC, Lin WW (1985) Study on the leiognathid fishes of Taiwan. Bull Inst Zool Acad Sin 24:125-138

Woodland DJ, Premchaoen S, Cabanban AS (2001) Leiognathidae. In: Carpenter KE, Niem VH (eds) FAO species identification guide for fishery purposes. The living marine resources of the Western Central Pacific, vol 5, bony fishes part 3 (Menidae to Pomacentridae). FAO, Rome, pp 2792-2823

Yamashita T, Kimura S, Iwatsuki Y (1998) Validity of the leiognathid fish, Gazza dentex (Valenciennes in Cuvier and Valenciennes, 1835), with designation of a lectotype, and redescription of $G$. minuta (Bloch, 1795). Ichthyol Res 45:271-280

Yamashita T, Kimura S, Iwatsuki Y (2001) A new species, Gazza squamiventralis, from the East Coast of Africa (Perciformes: Leiognathidae). Ichthyol Res 48:161-166 